\title{
RETURN ON INVESTMENT IN PV POWER PLANTS UNDER CHANGING SUPPORT REGIMES (SCHEMES)
}

\author{
ANNA M. KLEPACKA \\ KAMIL PAWLIK
}

\begin{abstract}
The production of renewable energy has been increasing in Poland in accordance with the EU mandate. Solar energy use, in particular, has been affected by regulations and the associated subsidy mechanism. The specific aim of the study was the verification of the influence exerted by renewable energy regulations on the amount of revenues and duration of the period when an investor can expect positive returns on operating a PV power plant. The analysis involved five scenarios and used financial and operational data shared by the existing $P V$ power plant in Jadowniki, Poland. Two scenarios refer to plants operating under the support mechanism applied before July 1, 2016, while three scenarios consider plants operating under the auction system that became the support mechanism for renewable energy producers on July 1, 2016. Scenarios I and II generate a positive NPV and IRR under the assumed conditions including the use of green certificates. For PV power plants operating since July 1, 2016, Scenarios III and IV show that the return is dependent on the auction price and the size of NPV and IRR discourages investment. Scenario $V$ assumes absence of support in the form of green certificates or through auction systems and generates loss. The continuing changes in the regulation of power generation from renewable energy sources, including solar energy, creates uncertainties that are likely to discourage investment in large commercial PV power plants in Poland.
\end{abstract}

Keywords: PV power plant, return on investment, regulatory regime.

JEL codes: Q42, Q47, Q48.

\footnotetext{
Anna M. Klepacka PhD., Warsaw University of Life Sciences, Faculty of Production Engineering, Department of Production Menagement and Engineering 164 Nowoursynowska St., 02-787 Warsaw, Poland; anna_klepacka@sggw.pl.

Kamil Pawlik Former graduate student, Warsaw University of Life Sciences, Faculty of Production Engineering, 164 Nowoursynowska St., 02-787 Warsaw, Poland; kpkamiil01@gmail.
} 


\section{Introduction}

The European Union (EU) imposed a requirement on all Member States to increase the share of power generated from renewable sources (Jeager-Waldau, Szabo, Scarlat and Monforti-Ferrario, 2011). The share of energy generated from renewable sources in Poland must reach 15\% by 2020 (Urząd Regulacji Energetyki, 2016a). As recently as 2014, Poland generated $11.4 \%$ of energy from renewable sources (EurObserv'ER, 2014). Renewable energy generation, especially solar energy, coincides with a national programme of lowering air pollution for 2013-2018. Solar energy can bring the benefits of limiting generation of carbon dioxide $\left(\mathrm{CO}_{2}\right)$ and other greenhouse gases (GHG) (Tudorache and Kreindler, 2010), and particulate matter, commonly associated with the use of coal, the primary fossil fuel used in Poland to generate electricity.

Recently, there has been a clear development of several forms of renewable energy in Poland. The most visible progress has been in the construction and utilization of wind power and solar radiation (Chochowski, 2008a, 2008b). Among new installations utilizing renewable energy, the bulk is represented by solar photovoltaic (PV) panels and wind mills $(77 \%)$, while the balance is hydropower plants (REN21, 2016).

Despite the rapid growth of solar and wind energy installations, their share in the total energy generated from renewable sources is still small and amounted to $10.4 \%$ for wind and $0.5 \%$ for solar in 2015 . Moreover, the share in electricity generated from renewable sources was $47.9 \%$ in the case of wind and a miniscule $0.3 \%$ for solar energy in Poland in 2015 (GUS, 2017).

Solar energy use is associated primarily with the purchase of solar panels used in generating heat for households rather than PV panels (Klepacka and Buska, 2015) due to the lack of regulations until 2017. In 2013 only a single project investment in a PV plant valued at EUR 6.65 million (4 MWp capacity) was reported in Poland (EurObserv'ER, 2014). In the same year, the capacity of the installed on-grid PV systems was 0.4 MWp, but dramatically increased to $19.7 \mathrm{MWp}$ in 2014. For comparison, the capacity installed in the off-grid PV systems was only $0.2 \mathrm{MWp}$ in 2013, and increased to 0.5 MWp in 2014 (EurObserv'ER, 2015). Due to changes in the solar energy support system discussed in the subsequent sections, the installed capacity of off-grid PV systems grew faster in 2015 (EurObserv'ER, 2017).

The specific aim of the study was the verification of the influence exerted by renewable energy regulations on the amount of revenues and duration of the period when an investor can expect positive returns on operating a PV power plant.

This study examines the profitability of solar energy generation under grandfathered and new support systems in Poland. Specifically, the analysis recognizes the use of "green certificates" (old system) and the auction mechanism (new system) in backing solar energy installations. The study applies two measures, NPV and IRR, to calculate the returns on investment in the PV solar power plant. The empirical analysis is based on the existing solar energy-generating facility in Jadowniki, Poland (Photo 1). Solar radiation intensity varies across Poland and the areas of particularly favourable conditions include Lubelskie Voivodeship, southern part 
of Mazowieckie and Wielkopolskie Voivodeships, areas along the Baltic coast and the mountains located in the south. The Jadowniki PV power plant is in an area with relatively high intensity of solar radiation and its performance is partially determined by the advantageous geographical location (Map 1 and Map 2).

This solar power plant has the capacity of $1 \mathrm{MW}$. The plant applies the PV panel system placed on tracks allowing positioning of the panels accordingly to the movement of the sun throughout the day. The generated energy is sold to the procuring agent determined by regulations to purchase all generated energy.

Electricity generated by the Jadowniki PV power plant directly contributes to the fulfillment of the EC mandate regarding the renewable energy share in total energy used. From the local perspective, the power plant location in rural area of Małopolskie Voivodeship may create jobs, as the agriculture importance in the region declines and land use shifts to non-agricultural use.

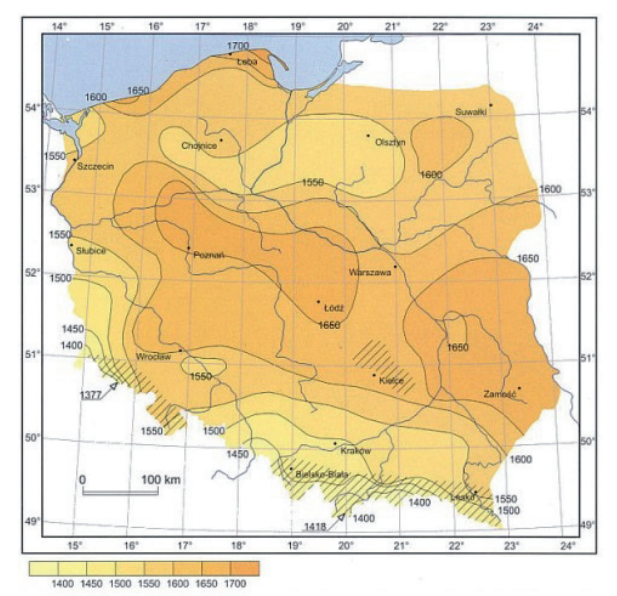

Map 1. Annual average number of sunshine hours in Poland.

Sorce: Lorenc (2005).

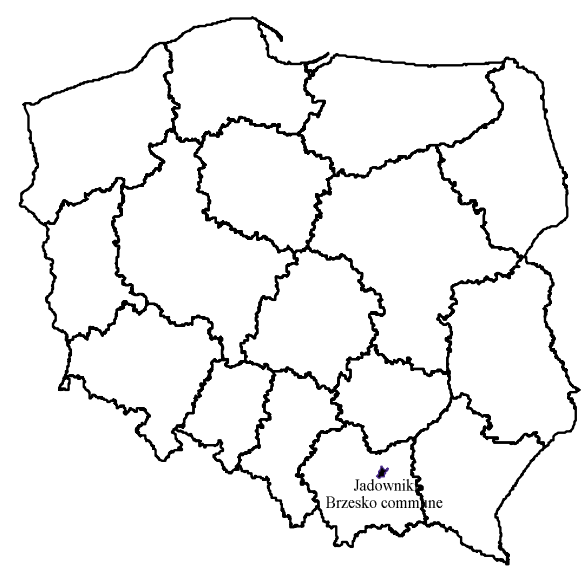

Map 2. The location of Jadowniki PV power plant in Brzesko commune in Małopolskie Voivodeship.

Source: own elaboration based on MapInfo.

\section{Materials and methods}

The selection of PV power plant in Jadowniki was dictated by its large capacity at the time of starting electricity production in 2015 , which was a novelty in Poland at that time. Additionally, gaining access to specific financial data and the operating costs is unusual because of the proprietary nature of such data regarding a non-hypothetical situation. The obtained information allowed us to consider several scenarios enabling to gain insights in the potential economic performance as regards timing of PV power plant construction and operation. 
The empirical analysis involves five scenarios of power plant profitability using a PV system. Return projections involve five scenarios and cover the period between 2016 and 2040, corresponding to the PV panel system expected life of 25-30 years. Two scenarios apply to solar power plants constructed prior to 2016 (such as the Jadowniki plant) and subjected to regulations used at the time of plant construction. Those power plants continue to participate in the support programme based on the so-called green certificates. The other three scenarios apply to solar power plants that became operational after July 1,2016. Such plants can participate in the new support programme using an auction mechanism to distribute a limited amount of subsidies. The increase of electric energy prices is based on projections of the Ministry of Economy. All scenarios assume that an investor in a solar power plant uses credit in the amount of $40 \%$ of total investment. The annual cost increase is assumed to equal $2 \%$.

Table 1 shows the assumptions for each of the five scenarios considered in the study. Investor's own resources include at least the cost of land on which the PV power plant is located (see Photo 1), which applies to Scenarios I, II, and V. In the case of Scenarios II and III, own resources provided by the investor are much larger, because the subsidy amounts only to $23 \%$ in Scenario II, while under Scenario III no subsidy is made available.

Furthermore, Scenarios I and II include the support for the electricity generated from renewable resources through the allocation of green certificates reflecting the regulations for PV power plants, which became operational prior to July 1, 2016. Scenarios III and IV receive support through the auction system, which became available for PV power plants starting electricity generation on or after July 1, 2016. For each of scenarios I, II, III, and IV the support amount per granted green certificate or a certificate obtained from the auction varies (Table 1). Investor acting under Scenario V does not receive any support through the auction or green certificate allocation from the onset of the PV power plant operation. In all scenario, the assumed discount rate is $3.5 \%$.

This study of the actually operating PV plant adds to the earlier literature that focused on hypothetical situations exploring the benefits of locating PV plants at various locations in other countries (for example, El-Shimy, 2009; Harder and MacDonald Gibson, 2011; Khalid and Junaidi, 2013; Chandel et al., 2014). The size of the PV plant in this study matches the natural solar radiation in the region. The analysis accounts for the effects of two different regulatory regimes regarding the support for renewable energy generation. The regulatory regimes are specific to the EU programme of support for utilization of solar energy. 
Table 1

Basic assumptions regarding factors used in five scenarios of investing and operating a PV power plant

\begin{tabular}{lrrrrr}
\hline & Scenario I & Scenario II & Scenario III & Scenario IV & Scenario V \\
\hline $\begin{array}{l}\text { Own contribution } \\
\text { (PLN) }\end{array}$ & 150,000 & 150,000 & $2,689,924.25$ & $4,322,229.8$ & 150,000 \\
Subsidy (\%) & 60 & 60 & 23 & None & 60 \\
$\begin{array}{l}\text { Form } \\
\text { of support }\end{array}$ & $\begin{array}{r}\text { Green } \\
\text { certificate }\end{array}$ & $\begin{array}{r}\text { Green } \\
\text { certificate }\end{array}$ & $\begin{array}{r}\text { Auction } \\
\text { system }\end{array}$ & $\begin{array}{r}\text { Auction } \\
\text { system }\end{array}$ & None \\
Support & 120.00 & 149.00 & 381.00 & 465.00 & None \\
amount (PLN) & $1,456,363.66$ & $868,253.41$ & $-556,567.55$ & $-2,027,888.85$ & $-1,250,459.95$ \\
NPV (PLN) & 6,94 & 11,04 & 1,34 & $-1,20$ & $-2,76$ \\
IRR (\%) & $9,735,046$ & $10,297,636$ & $10,488,459$ & $12,120,764$ & $7,403,737$ \\
Revenues (PLN) & $7,625,365$ & $7,625,365$ & $7,625,365$ & $7,625,365$ & $7,625,365$ \\
Costs (PLN) & & & & &
\end{tabular}

Source: own study based on the data from the Jadowniki PV power plant.

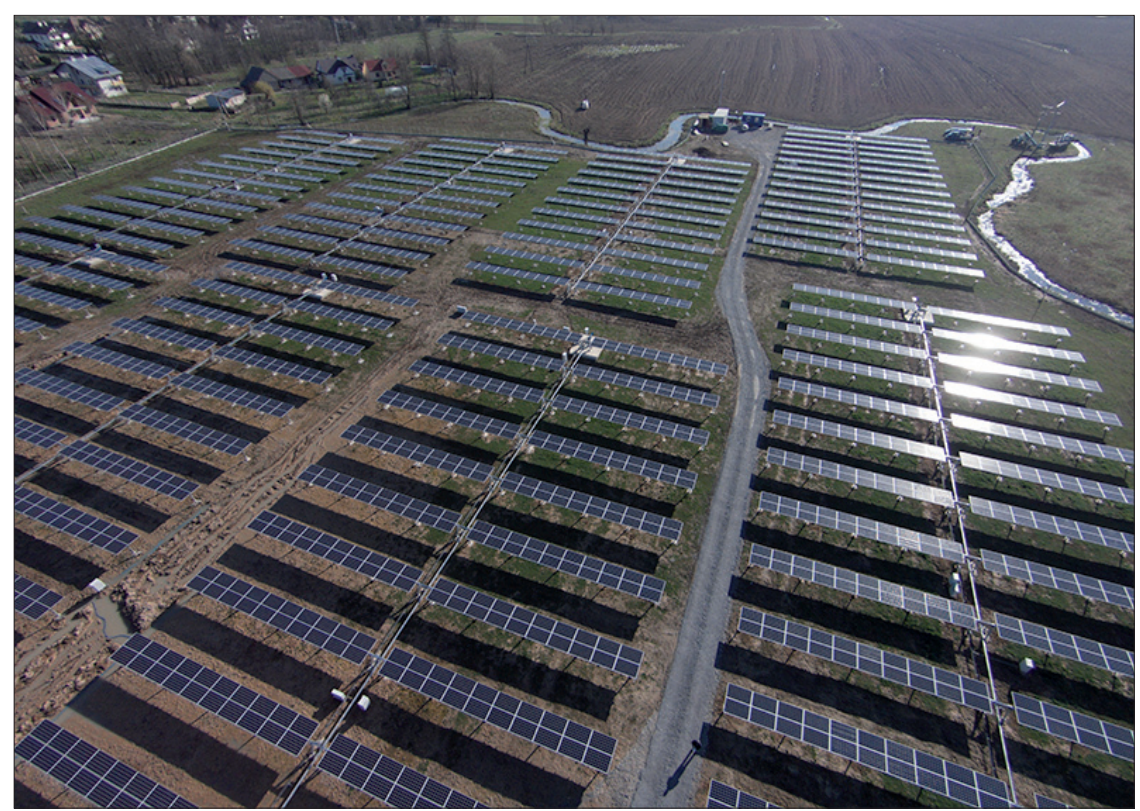

Photo 1. PV power plant in Jadowniki, Malopolskie Voivodeship, Poland.

Source: photo provided by the Jadowniki PV power plant. 


\section{Results and discussion}

\section{Solar energy sector development in Poland}

\section{Solar radiation in Poland}

Conditions in Poland are similar to those in the neighbouring countries of Germany and Czechia. Solar energy radiation ranges from $950 \mathrm{kWh} / \mathrm{m}^{2}$ to 1250 $\mathrm{kWh} / \mathrm{m}^{2}$ in Poland. The average number of sunshine hours amounts to $1600 \mathrm{hrs} /$ year (Instalcje Budowlane, 2017). For example, on average, the centrally located Mazowieckie Voivodeship receives 1550-1600 hrs in its northwestern region and 1600-1650 hrs of sunshine per year in its eastern region. Małopolskie Voivodeship, located in southeastern Poland, receives 1500-1550 hrs of sunshine per year (Map 1). Solar radiation is unevenly distributed across the year. Nearly $80 \%$ of solar radiation occurs in the spring-summer period in a typical year (Mientus, 2011), especially from May to July (Knyps, 2010).

\section{Solar collectors and PV panels}

Solar collectors differ from PV panels in their design, operation, and type of generated energy. The PV panels convert solar radiation into electricity and without any additional generators they can power electric equipment. Solar collectors generate heating energy by converting solar energy and supply, for example, hot water for household use or heating. Although PV panels could also heat water with the use of a heating device, from an economic standpoint such use of PV panels is costly and inefficient. In this capacity, their efficiency reaches only $20 \%$ as compared to a solar collector efficiency of $85 \%$ (kolektorowo.pl, 2016).

A single PV panel generates between $0.5 \mathrm{~V}$ and $2 \mathrm{~V}$. Its capacity depends on its surface area, while the capacity of the system depends on the number of individual panels. Panels can be mounted on tracks assuring a larger volume of produced electricity (Räuber, 2004). Panels on tracks change the angle of their position with regard to sun movement. As a result, the PV panel efficiency may increase by as much as 30\% (Anderson, Dohan, Sikora, Bitar and McNeill, 2003; Sefa, Demirtas and Colak, 2009).

Electricity generated by the PV panels cannot be sold unless it satisfies specific requirements. To assure the required properties, the direct current requires conversion into the alternate current using a voltage convertor. In addition, a transformer is required to change the voltage and send electricity from the off-grid PV power plant system to an on-grid system (Kahl, 1984).

\section{Production of energy using solar radiation}

Photovoltage is still a relatively new technology in Poland. This sector grows in response to demand from households and companies interested in microinstallations. By the end of 2013, the PV power plant capacity was 4.2 MWp, of which $1.8 \mathrm{MWp}$ was included in the on-grid system (EurObserv'ER, 2015). In May 2014 , there were $29 \mathrm{PV}$ power plants in the on-grid system with a total capacity of 
3.8 MWp and about 200 micro-plants with a total off-grid capacity of $2.8 \mathrm{MWp}$. Throughout 2014, the growth of the sector was rapid and added a total of $26 \mathrm{MWp}$ capacity, a five fold increase as compared to 2013. In 2015, the installed PV capacity amounted to $108 \mathrm{MWp}$ continuing the rapid expansion of the sector. Total on- and off-grid installed PV capacity amounted to 195.7 MWp in Poland in 2016 (EurObserv'ER, 2017).

Despite the rapid growth of PV installations, Poland's share of the capacity installed in Europe was negligible and represented $0.03 \%$ at the end of 2014 (EurObserv'ER, 2014). Although it tripled in 2015, it was still only 0.09 (EurObserv'ER, 2016). Overall, the total capacity of all PV installations is small in Poland as compared to the other EU countries (Klepacka and Zalewska, 2016).

\section{Prices of photovoltaic cells in recent years}

Farmer and Lafond (2016) reported that the costs of a PV panel decreased at about $10 \%$ annual rate since 1980 . The trend is expected to continue although there is a 5\% probability that the price in 2030 will be higher compared to prices in 2013 . The continution of the declining trend in prices implies that in ten years solar energy could satisfy one fifth of the global demand for electricity. The International Energy Agency (IEA) estimates that under the most optimistic scenario for renewable energy utilization, solar power plants will supply $16 \%$ of global energy needs no earlier than 2050 (creconsulting.pl, 2016). The decline in costs of PV technology in the period between 2009 and 2013 is comparable to the past cost decline in the IT sector. The PV panel prices have decreased by $80 \%$ since 2008 and this tendency is expected to continue (IRENA, 2014). Price changes will affect the return on investment in future PV power plants, but not in currently operating installations.

\section{Solar energy utilization support programme in Poland}

\section{The system of green certificates}

Green certificate is the common name for a Tradable Renewable Energy Certificate (TREC) (Brick and Visser, 2009). Such certificates represent a specific amount of eletricity produced from renewable sources. They have been created in response to the mandate to use renewables as a source of energy in the EU and their trading provides flexibility in meeting the target imposed by regulations. The system of green certificates was first implemented by the UK government in Europe. It was followed by the regions of Flanders and Wallonia in Belgium and the country of Italy. Poland introduced the Renewable Energy Certificate System (RECS system) in 2005 (Linden et al., 2005). However, the initial law defining the system of green certificates was already included in the Energy Act passed on April 10, 1997 supplemented by later amendments (Obiweszczenie, 2006). The system of green certificates started to operate in 2005 coinciding with the new regulations changing the obligatory purchase of energy from renewables.

Green certificates were created as a result of imposing a requirement on companies selling energy to the ultimate buyers to obtain and present to the president of the Energy Regulatory Agency (pl. Urząd Regulacji Energii, URE) a specific 
number of certificates proving that the sold electricity originated from renewable sources (Green Energy Poland SA, 2016). Companies unable to present green certificates in an adequate number have to pay fees to the National Fund of Environmental Protection and Water Management (Polish acronym NFOŚiGW).

A green certificate represents a property right that is created as a result of conversion of the certificates of energy origin issued by the president of URE. The process of conversion results automatically at the time of registering in the official Register of Certificates of Origin. Each generated certificate of origin referring to electricity from renewables generates simultaneously a green certificate. A single green certificate indicates the origin of $1 \mathrm{kWh}$ (Przewodnik dla przedsiębiorcy, 2016) and the number of generated green certificates corresponds to the volume of energy. The entity registering the generation of electricity from renewable sources obtains the green certificates, if the facility started the generation before July 1, 2016 (Ministerstwo Energii, 2016). The certificates exist only in electronic form evidenced in the registration system. They do not have an expiration date and are liquidated at the request of their current owner.

Green certificates, once generated, are subject to trade on the exchange. The exclusive exchange for trading green certificates is the Energy Exchange (Towarowa Giełda Energii, S.A.) in Poland. The Exchange manages the Register of Certificates of Origin and the trading of certificates of origin on the dedicated Market of Property Rights. The Committee of Financial Supervision assures the safety of the exchange operations.

The system of green certficates will function until 2030. Producers of electricity from renewable energy sources could have joined the system through the end of 2015 (Rynek Praw Majątkowych, 2016). The total value of support provided within the system of green certificates amounted to PLN 30 billion in 2006-2015. The support permitted the increase of the capacity of renewable energy power plants in Poland from 1,158 MW in 2005 to 7,829 MW in 2016 (as of March 31, 2016 according to the president of URE). The increased capacity has been reflected in the growth of electricity produced using renewables from $3.76 \mathrm{TWh}$ in 2005 to 21.08 TWh in 2015 (Ministerstwo Energii, 2016). Currently, green certificates are issued only to the already exisiting facilities, i.e. those that started to operate before July 1, 2016 (Ministerstwo Energii, 2016; gramwzielone.pl, 2015c).

\section{The exchange-based system}

New power plants that have started generating electricity from renewable sources can receive the support under the auction system. This system, based on the contract difference using an auction, was scheduled to begin on January 1, 2016, but despite "high expectations of the sector and the government promises" (Article 4) was postponed until July 1, 2016 (Magazyn Biomasa, 2016). Initially, the system was created by law on February 20, 2015, but the law was amended on June 22, 2016. Changes in regulations led to the date shift.

Under the auction system, the bid winners are guaranteed the sales of electricity for 15 years at the winning price. The price will be adjusted to reflect the inflation 
rate (gramwzielone.pl, 2015c). In accordance with the regulations, the auction winning price cannot exceed the government set price called the reference price. The reference price is set in PLN per 1 MWh for a given calendar year (Ustawa, 2016). The reference price determines the investment support in addition to the support provided through the auction.

The auction will use the electronic platform accessible at https://ipa.ure.gov.pl/ logowanie. Between May 24 and August 12, 2016, the website conducted three test sessions of the auction's electronic platform. It was expected to offer the opportunity for those generating electricity from renewables to become familiar with the principles of the auction's functioning (Urząd Regulacji Energetyki, 2016b).

Indeed just before the end of 2016, the auction took place on December 30 . The completed auction involved three baskets for facilites with the capapcity of less than $1 \mathrm{MW}$. The beneficiaries of the auction were 140 projects, mostly biogas plants, but also small hydroelectric plants, and a total of 84 projects involving solar energy and a handful of wind mill generators. The average price (after subtracting the subsidy) for the new PV plants was 353.78 PLN/MWh. The price exceeded the prices at recent auctions in Germany, but the taxes, and financial and technological costs were also higher. According to the President of the Renewable Energy Institute, the previous system of green certificates was characterized by lower administrative costs as copared to the auction and capable, after some improvements, of supplying less expensive energy without the creation of a bureacratic structure. Government negligence delayed the auction and exacerbated risk exposure for the State Treasury and investors. In an unstable political and institutional environment, the greatest challenge facing investors is that the public support system lacks a simple notification mechanism; subsidies are usually obtained at the investment stage (Wiśniewski, 2017).

The subsequent auctions were held on June 29-30, 2017. Auction participants would be given the opportunity, for the first time, to generate electricity from renewable sources using equipment with a capacity of less than $1 \mathrm{MW}$. The auction winners included 352 offers from 236 producers with an average energy price of 296.94 PLN/MWh (http://gramwzielone.pl/trendy/27264/ure-podal-wyniki-aukcji-dla-oze-z-29-30-czerwca).

In response to the outcome of these auctions, the Ministry of Energy began to promote PV plants with a capacity of up to $1 \mathrm{MW}$, offering a contract for 0.3-0.4 TWh annually for 2016-2017, with a long-term goal of 10 TWh annually. In the case of installtions with capacity no larger than $1 \mathrm{MW}$, plans are under consideration for adding $800 \mathrm{MW}$ to the capacity of the grid.

Less than one half of those installations won at auctions creating possibilities for expansion. Additionally, since May 4, 2015, contracts were signed or approved for PV installations with the capacity of $1.2 \mathrm{GW}$. However, during auctions, PV projects compete with wind mill projects, but with proper planning the projects may be classified as plants of capacity less than $1 \mathrm{MW}$. PV installtions are experiencing rapid growth, have a minimal effect on the environment, and do not cause public protests (Schnell, 2018). 
At the end of 2017, the Ministry of Energy proposed a reference price for auctions planned for 2018. The reference price established a ceiling for the sale of energy from various renewable sources in offers submitted in 2018. The proposed reference price for 2018 auctions differed from prices in 2016 and 2017. The price was increased for the energy generated by biogas plants, but lowered for the PV plants. For the PV plants with a capacity up to $1 \mathrm{MW}$, the proposed price for electricity was $420 \mathrm{PLN} / \mathrm{MWh}$ versus $450 \mathrm{PLN} / \mathrm{MWh}$ in 2017, a 7\% decrease. The price in 2016 was 465 PLN/MWh. The proposed reference price for PV plants with a capacity exceeding $1 \mathrm{MW}$ was $400 \mathrm{PLN} / \mathrm{MW}, 6 \%$ less than the price of $425 \mathrm{PLN} / \mathrm{MWh}$ in 2017, and considerably lower than 445 PLN/MWh in 2016 (Schnell, 2018).

In early March 2018, the government adopted a draft law changing renewable energy regulations and related laws. The proposal changes the auction mechanism supporting renewable energy. The existing seven classes of renewable energy projects is to be replaced by five (by elimination of "thermal treatment of solid waste" and "energy clusters", and creation of "hybrid installations"). The proposed law would allow the electronic submission of offers using the public service platform ePUAP as well as on paper (Chojnacki, 2018).

Experts maintain that the auction can still be held in the third, and at the latest, in the fourth quarter in 2018. Such timing would allow some of the investors to complete their projects and still connect them to the grid in 2019, while producing energy the whole year. That would help to meet the goal mandated by the European Commission with a 2020 deadline. Projects that could be completed relatively quickly involve small PV plants and several ready wind mill operations awaiting connection. The proposed law creates the largest class "wind on land, photovoltaics" in the revised support system that would apply to 1870 MW capacity, including 870 MW from PV plants (Chojnacki, 2018).

An important issue of interest to investors that was proposed in the new law is the shortening of the investment period to 18 months (previousely 24 months). Another was the financing of the investment, which depends on the bank's decision to take the risk and provide credit for the renewable energy installation under the auction system, or, given the past failures with wind mills, refuse credit (Chojnacki, 2018). Some experts expressed the opinion that the contracts for connecting to the grid concluded prior to May 4, 2015, should be extended, including the PV installations, if the projects would win the auction before May 4, 2019 (Schnell, 2018).

Most recently, on June 29, 2018, the proposed bill on modification of the renewable energy regulations and related documents was signed into law. Specific rgulations will be issued by the Ministry of Energy, including the fullfilment of international obligations. The modifications assure the full agreement of the law of February 20,2015, about the renewable energy and the regulations governing public subsidies. The requirement resulted from the obligations with regard to the European Commission and the EU regulations. The new law modifies the classification of projects in the auction system by accounting for the specific competitiveness of various renewable energy sources. The aim was to increase the competitiveness 
of offers submitted for the auction lowering the costs of the support programme (http://odnawialnezrodlaenergii.pl/oze-aktualnosci/item/3916-prezydent-podpisalustawe-pozwalajaca-na-efektywniejsze-wykorzystanie-oze).

\section{Economic performance of the PV power plant in Jadowniki, Poland under alternative scenarios}

The PV plant that serves as the basis for analysis in this study is located in Jadowniki in Malopolskie Voivodeship in southeastern Poland. The plant's total area is 3 hectares and has been operating since July of 2015. It uses 4,000 monocrystal PV panels, each with the capacity of $260 \mathrm{~W}$. Panels are mounted on single axis tracks that follow the sun's movement using a DC motor (Tudorache and Kreindler, 2010). This is the first PV plant with panels mounted on trackers in Poland (gramwzielone.pl, 2015a). All generated energy is sent to a voltage convertor, and a transformer is connected to the outside grid. The expected electricity generation used in the presented scenarios is that used by investors in the Jadowniki plant. In addition, the operating costs in this study are based on the actual operating costs observed during the initial period of plant operation.

\section{Economic viability of the PV farm}

The long-term economic viability of a solar farm depends on its sustained profitability. Among key factors used in this study to determine the return on investment is the amount of invested financial resources and the operational costs of the PV farm. In this type of renewable energy regulations are important, reflected in the possibility of obtaining financial support and its amount as related to the investor's own resources (Laudyn, 1999). The interest on credit and credit conditions as well as the amount of subsidy are helpful in assessing the ability of the PV farm to generate returns (Rogowski, 2008; O'Brien, 2008). Own capital and expected return on all invested capital are considered initial investment decision inputs (Rogowski, 2008; O’Brien, 2008).

Costs. Costs are financial outlays resulting from undertaking a specific activity and influence the return on investment. Operating costs are associated with the generation of energy from PV panels. In the case of a PV power plant, the largest share of costs is associated with the initial investment (Laudyn, 1999). Four categories of expenses include the preparation of the project, necessary licenses and permits, purchase of adequate land, and credit application (if needed). Another expense item is associated equipment necessary to install and operate panels. Transportation expenses and installation are a separate cost category. Finally, there are costs associated with integration of a PV power plant into the electric grid.

Revenues. The primary revenue source of PV power plants is the sale of generated energy. In Poland, PV power plants that began operation before July 1, 2016 obtain revenues from the sale of energy and green certificates. The PV power plants that have been operating since July 1, 2016 generate revenue from sales of energy at rates guaranteed for the first 15 years of plant operation. The offered price cannot exceed the reference price for the given source of energy as listed by the Ministry of the Economy. 
PV power plants that started to generate energy after July 1, 2016 can also receive support under the auction mechanism. The expected auction opening system took place at the end of 2016. Alternatively, an investor or operator of a PV power plant who does not participate in an auction (or whose bid is too high, assuming the auction functions) can sell energy to a buyer designated by the government. The latter is obligated to purchase all generated energy (Ligus, 2009).

Financing. Drury (1998) lists three sources of financing in the case of a PV power plant: investment capital, subsidies, and credit. In the case of the PV power plant considered in the current study, the subsidy accounted for $60 \%$ of the financing and the balance was supplied with bank credit. An additional cost was the purchase of the necessary land with an estimated value of PLN 150,000 (approximately EUR $35,800)$ (see Table 1).

Profitability indicators. Efficiency and profitability indicators include measures applied in the initial evaluation of investment. The current study applies measures that consider revenues and expenses over time. The net present value (NPV) is the discounted value from the time of initial investment, operating costs over the life of the investment, and revenues (Rogowski, 2008; Drury, 1998). The standard formula is:

$$
N P V=-N_{0}+\frac{N C F_{1}}{(1+d)}+\frac{N C F_{2}}{(1+d)^{2}}+\cdots+\frac{N C F_{n}}{(1+d)^{n}}=\sum_{t=1}^{n} \frac{N C F_{i}}{(1+d)^{t}}-N_{0}
$$

where:

$N_{0} \quad-$ is the initial investment amount,

$N C F_{t}$ - is the stream of net transfers in period $t$,

$d \quad-$ is the discount rate,

$n \quad-$ is the number of years in the analysed period (Marcinek, 2002).

An investment is profitable if NPV $\geq 0$ and any such investment may be considered worth the effort and risk. The assumed discount rate determines the NPV. The discount rate may equal the interest rate on the long-term credit (Czerska, 2002) or correspond to a near risk-free investment such as short-term government debt instruments.

Another measure of return is the internal rate of return (IRR). IRR is a discount rate with the NPV equal to zero. An investment is considered profitable if the discount rate is less than the IRR. Consequently, the higher the IRR relative to the discount rate, the more profitable the investment (Rogowski, 2008; Sawicki, 1998). The formula is:

$$
\sum_{t=0}^{n} \frac{N C F_{t}}{(1+I R R)^{t}}=0
$$




\section{Alternative scenarios of the PV farm operation}

Five scenarios are developed to account for PV power plants constructed and operated before and after July 1, 2016. The scenarios reflect differences in the subsidy systems. Scenarios I and II apply to power plants operating before 2016 and eligible for subsidies through the use of green certificates. Scenarios III and IV refer to current regulations and the new support system based on the auction mechanism. Scenario V is a purely commercial venture that generates revenue only from electricity sales without obtaining any support. Table 2 shows features that apply to each of the five scenarios reflecting the actual conditions of the PV power plant in Jadowniki (for example, credit amount and interest), and the assumptions about future conditions (for example, the rate of increase in operating costs).

A number of initial values used in calculating the return on PV power plant investment are identical for all considered scenarios (Table 2). The time horizon of the investment corresponds to the lower range of expected life of a PV panel ( 25 years). The annual amount of generated energy reflects the average solar radiation conditions for the general location of the Jadowniki PV plant in southeastern Małopolskie Voivodeship. The projected electricity prices were generated by the Ministry of Energy. Annual operating costs are based on the actual performance of the Jadowniki PV plant established after the first few months of operation and are assumed to increase at a $2 \%$ annual rate. All scenarios assume a $3.5 \%$ annual interest rate on a ten year credit in the amount of PLN 3,510,804.93 (EUR 837,901). All monetary values expressed in PLN were converted to euros at the average exchange rate listed by the National Bank of Poland on July 1, 2015. (NBP, 2016). Overall, the total costs do not differ across various scenarios (Table 2).

\section{Scenarios I and II}

The price of a green certificate in Scenario I is assumed to be PLN 120 (EUR 28.64) throughout the duration of the support period. This scenario also assumes the subsidy from the European Union programme in the amount of $60 \%$ of the investment cost, or PLN 4,172,229.08 (EUR 995,758.70). The investor provides 3 hectare land parcel valued at PLN 150,000. Scenario II differs from Scenario I in the assumed price of green certificates (Table 3). The price equals PLN 149 (EUR 35.56) and corresponds to the average price of green certificates in the two years preceding the new regulations (effective July 1, 2016).

The net returns differ, especially once the credit is paid off at the end of the tenth year of plant operation (Table 3). But even earlier, the negative net flow is considerably smaller under Scenario II, easing the management of the whole plant. Both scenarios generate a positive NPV and IRR. However, for Scenario II the IRR is $11.04 \%$, nearly twice the amount of the IRR generated under Scenario I (6.94\%). Still, a PV power plant that started operations before July 1, 2016 is expected to be economically viable. 
Table 2

Volume of the generated energy, expected energy prices, annual operational costs, credit repayment schedule, and total costs used in the alternative scenarios to calculate returns for the Jadowniki solar PV power plant in Poland for 2016-2040

\begin{tabular}{|c|c|c|c|c|c|}
\hline Year & $\begin{array}{c}\text { Generated } \\
\text { energy, in MWh }\end{array}$ & $\begin{array}{l}\text { Energy price } \\
\text { per MWh }\end{array}$ & $\begin{array}{l}\text { Operating } \\
\text { costs }\end{array}$ & $\begin{array}{c}\text { Credit } \\
\text { installment }\end{array}$ & $\begin{array}{c}\text { Operating } \\
\text { costs and credit } \\
\text { installment }\end{array}$ \\
\hline 2016 & 1359.8 & 41.21 & $25,761.52$ & $99,374.87$ & $125,136.39$ \\
\hline 2017 & 1350.3 & 43.62 & $26,276.75$ & $99,374.87$ & $125,651.62$ \\
\hline 2018 & 1340.9 & 45.94 & 26802.28 & $99,374.87$ & $126,177.15$ \\
\hline 2019 & 1331.5 & 48.33 & $27,338.33$ & $99,374.87$ & $126,713.20$ \\
\hline 2020 & 1322.1 & 51.12 & $27,885.09$ & $99,374.87$ & $127,259.97$ \\
\hline 2021 & 1312.9 & 53.69 & $28,442.79$ & $99,374.87$ & $127,817.67$ \\
\hline 2022 & 1303.7 & 54.66 & $29,011.65$ & $99,374.87$ & $128,386.52$ \\
\hline 2023 & 1294.6 & 55.27 & $29,591.88$ & $99,374.87$ & $128,966.76$ \\
\hline 2024 & 1285.5 & 55.80 & $30,183.72$ & $99,374.87$ & $129,558.59$ \\
\hline 2025 & 1276.5 & 56.25 & $30,787.40$ & $99,374.87$ & $130,162.27$ \\
\hline 2026 & 1267.6 & 56.49 & $31,403.14$ & - & $31,403.14$ \\
\hline 2027 & 1258.7 & 58.00 & $32,031.21$ & - & $32,031.21$ \\
\hline 2028 & 1249.9 & 59.03 & $32,671.83$ & - & $32,671.83$ \\
\hline 2029 & 1241.1 & 59.08 & $33,325.27$ & - & $33,325.27$ \\
\hline 2030 & 1232.5 & 58.95 & $33,991.77$ & - & $33,991.77$ \\
\hline 2031 & 1223.8 & 59.51 & $34,671.61$ & - & $34,671.61$ \\
\hline 2032 & 1215.3 & 60.08 & $35,365.04$ & - & $35,365.04$ \\
\hline 2033 & 1206.8 & 60.65 & $36,072.34$ & - & $36,072.34$ \\
\hline 2034 & 1198.3 & 61.22 & $36,793.79$ & - & $36,793.79$ \\
\hline 2035 & 1189.9 & 61.80 & $37,529.66$ & - & $37,529.66$ \\
\hline 2036 & 1181.6 & 62.39 & $38,280.26$ & - & $38,280.26$ \\
\hline 2037 & 1173.3 & 62.98 & $39,045.86$ & - & $39,045.86$ \\
\hline 2038 & 1165.1 & 63.58 & $39,826.78$ & - & $39,826.78$ \\
\hline 2039 & 1157.0 & 64.18 & $40,623.31$ & - & $40,623.31$ \\
\hline 2040 & 1148.9 & 64.79 & $41,435.78$ & - & $41,435.78$ \\
\hline Total & $31,287.5$ & - & $825,149.05$ & $993,748.73$ & $1,818,897.78$ \\
\hline
\end{tabular}

Source: jak do tab. 1. 


\section{Scenarios III, IV, and V}

The three scenarios reflect new regulations and consider the auction as the mechanism determining the amount of subsidy to a PV power plant. Scenario III assumes the auction price at PLN 381 (EUR 90.93) per MWh (Table 4) that resulted from the increased restrictions on renewable energy passed on February 20, 2015 (Article 39) (Ustawa, 2015). The price level corresponds to the average price with regard to the reference price on the German market (gramwzielone.pl, $2015 \mathrm{~b}$ ), where the former amounted to $82 \%$ of the latter after the initial series of auctions. Under the regulations, the highest subsidy, at PLN 381 per MWh, is PLN 1,632,304.83 (EUR 389,571.6). An investor must provide PLN 2,689,924.25 (EUR $641,986.7)$ under that scenario.

The amount of subsidy has been calculated as the difference between the value of total generated energy for the period of 15 years (i.e. the period during which the subsidy is in place) using a reference price and the amount of subsidy assuming the price is determined at the auction (i.e. PLN 381). Specifically: (Reference price $\mathrm{x}$ energy volume generated during a 15-year period) - (the average electricity price announced by the government energy agency $\mathrm{x}$ energy volume generated during a 15year period $)$, or $(\mathrm{PLN} 465 \times 19,427.57 \mathrm{MWh})-(\mathrm{PLN} 172.75 \times 19,427.57 \mathrm{MWh})=$ PLN 5,677,707.33 (EUR 1,355,061); and, (Auction-determined price x energy volume generated during a 15-year period) - (the average electricity price announced by the government energy agency $\mathrm{x}$ energy volume generated during a 15 -year period), or (PLN $465 \times 19,427.57 \mathrm{MWh})-(\mathrm{PLN} 172.75 \times 19,427.57 \mathrm{MWh})=$ PLN 5,677.707.33 (PLN $381 \times 19,427.57 \mathrm{MWh})-($ PLN 172.75 x 19,427.57 MWh $)=$ PLN 4,045,791.45 (EUR 965,582.7). The maximum subsidized amount equals PLN $1,631,915.88$ (EUR 389,478.7) and that amount lowers the costs and influences the return in Scenario III. The return is heavily dependent on the auction price. Under this scenario, the NPV is negative, PLN -556567.55 (EUR -132,832.4), and the IRR is $1.34 \%$. The projections are unlikely to attract investors given the new support mechanism introduced after July 1, 2016 at the assumed auction price.

Scenario IV assumes the auction price at the maximum level allowed by the renewable energy law (Ustawa, 2015). The price is PLN 465 (EUR 110.92) per MWh (Ustawa, 2015) and equals the reference price (gramwzielone.pl, 2015b). Under those circumstances, the PV power plant is unable to obtain a subsidy. The investor has to provide funds in the amount of PLN 4,322,229.08 (EUR 1,031,558). This scenario produces negative NPV and IRR in the amount of PLN -2,027,888.85 (EUR $-483,983)$ and $-1.20 \%$, respectively.

Scenario V assumes a subsidy in the amount of $60 \%$ of the estimated investment cost from the funds provided under the EU programme, but the investor is excluded from participation in the auction (Table 5). Revenues are exclusively obtained from the sale of electric energy to the government-designated buyer (the buyer is a company named in the law). Among all considered scenarios, Scenario V is least attractive and generates substantial loss to an investor. The IRR is $-2.76 \%$, and the NPV is a loss in the amount of PLN 298,275.40 (EUR 71,148.39). 
曾

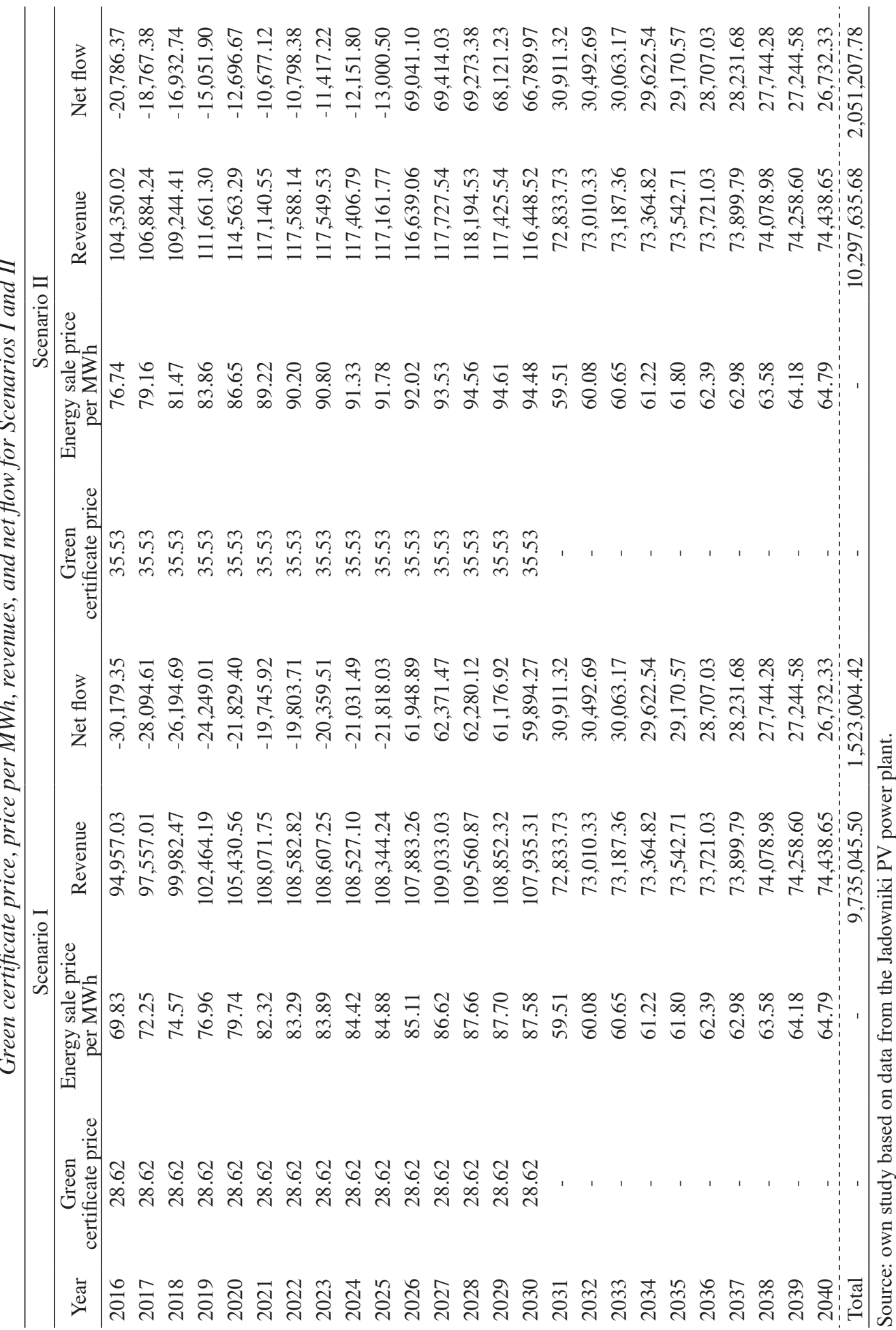


憘

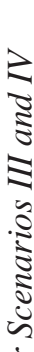

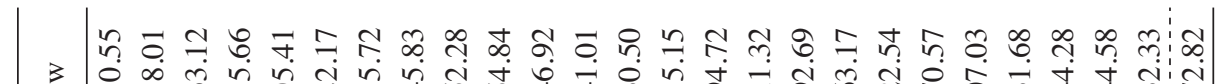

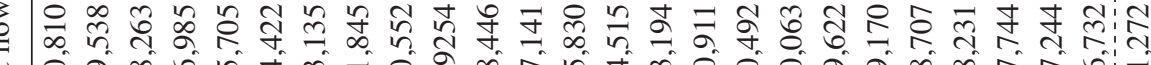

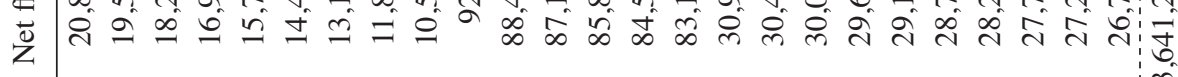

ศ ชู สุ

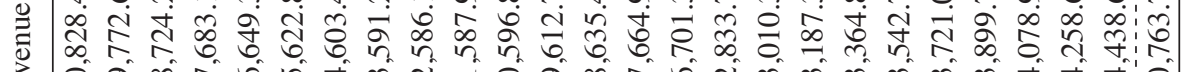

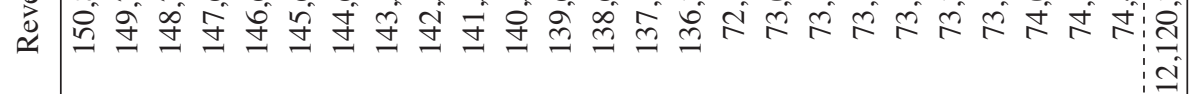

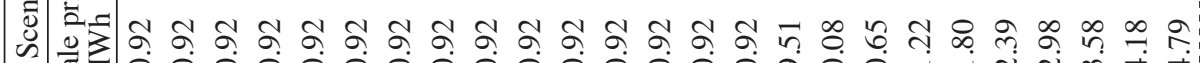

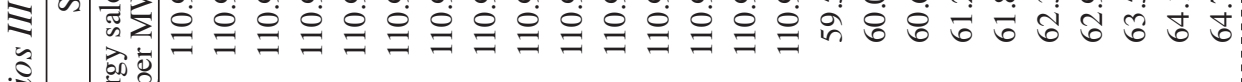

定

$\grave{\Xi}$

$\frac{3}{\sqrt[3]{3}}$

בे

되

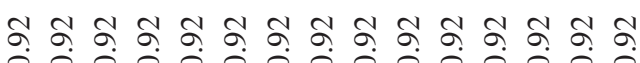

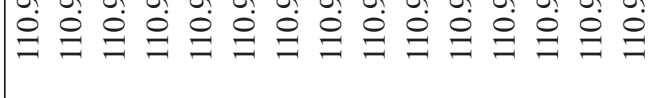

$\infty$ ț

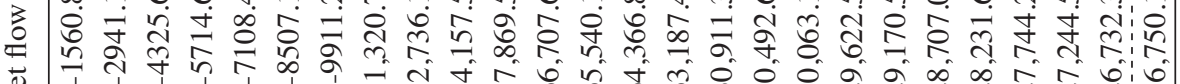
चै त भ जि

- $\bar{n}$ 華

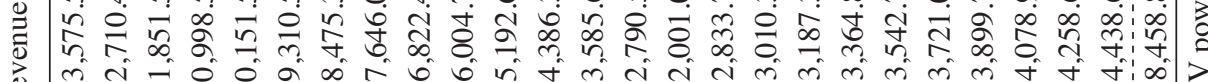

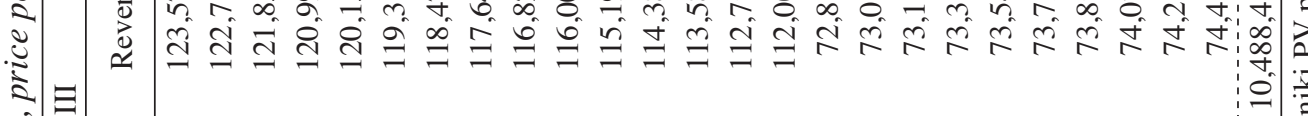

포

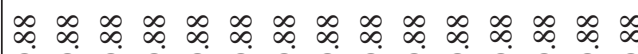

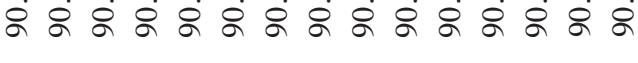

龸

䒕 
Table 5

Energy sale price, revenue, and net flow for Scenario $V$

\begin{tabular}{|c|c|c|c|}
\hline \multicolumn{4}{|c|}{ Scenario V } \\
\hline Year & $\begin{array}{l}\text { Energy sale price } \\
\text { per MWh }\end{array}$ & Revenue & Net flow \\
\hline 2016 & 41.21 & $56,033.57$ & $69,102.82$ \\
\hline 2017 & 43.62 & $58,906.01$ & $66,745.61$ \\
\hline 2018 & 45.94 & $61,602.02$ & $64,575.13$ \\
\hline 2019 & 48.33 & $64,352.41$ & $62,360.79$ \\
\hline 2020 & 51.12 & $67,585.56$ & $59,674.40$ \\
\hline 2021 & 53.69 & $70,491.66$ & $57,326.00$ \\
\hline 2022 & 54.66 & $71,265.80$ & $57,120.73$ \\
\hline 2023 & 55.27 & $71,551.45$ & $57,415.31$ \\
\hline 2024 & 55.80 & $71,730.69$ & $57,827.91$ \\
\hline 2025 & 56.25 & $71,805.40$ & $58,356.87$ \\
\hline 2026 & 56.49 & $71,600.19$ & $32,559.61$ \\
\hline 2027 & 58.00 & $73,003.94$ & $33,187.92$ \\
\hline 2028 & 59.03 & $73,783.99$ & $33,300.85$ \\
\hline 2029 & 59.08 & $73,325.88$ & $32,400.50$ \\
\hline 2030 & 58.95 & $72,657.56$ & $31,319.29$ \\
\hline 2031 & 59.51 & $72,833.73$ & $30,911.32$ \\
\hline 2032 & 60.08 & $73,010.33$ & $30,492.69$ \\
\hline 2033 & 60.65 & $73,187.36$ & $30,063.17$ \\
\hline 2034 & 61.22 & $73,364.82$ & $29,622.54$ \\
\hline 2035 & 61.80 & $73,542.71$ & $29,170.57$ \\
\hline 2036 & 62.39 & $73,721.03$ & $28,707.03$ \\
\hline 2037 & 62.98 & $73,899.79$ & $28,231.68$ \\
\hline 2038 & 63.58 & $74,078.98$ & $27,744.28$ \\
\hline 2039 & 64.18 & $74,258.60$ & $27,244.58$ \\
\hline 2040 & 64.79 & $74,438.65$ & $26,732.33$ \\
\hline Total & - & $7,403,736.53$ & $665,809.47$ \\
\hline
\end{tabular}

Source: own study based on data from the Jadowniki PV power plant. 


\section{Conclusions}

The study uses the existing PV power plant in Jadowniki, Małopolskie Voivodeship as the basis for the analysis of returns on investment rather than analysing a hypothetical location. In a rare level of cooperation, the PV plant management shared the financial information and technical performance details enabling the examination of five possible scenarios. The variable returns provide a measure of economic viability of investing in PV power plants and indirectly shed light on the possible role of solar energy in electricity generation in Poland and the obligation regarding the share of renewable energy within total energy use by 2020 .

The scenarios account for five situations, where PV power plants operating before July 1, 2016 are subject to a support system based on green certificates, while those becoming operational on or after July 1, 2016 could obtain support through auctions organized by the Energy Regulatory Agency. Two investment scenarios using green certificates as the form of support for renewable energy generation indicate substantial returns under the assumed conditions. Those scenarios contrast with two scenarios using the auction mechanism as a source of generating support to a PV power plant investor. Under the auction-determined price for electricity, the returns are unsatisfactory and the investment leads to losses. Similarly, a PV power plant operating without any support is economically infeasible under the conditions considered in the analysis.

The study using information from the Jadowniki PV power plant exemplifies how change in the regulatory regime can dramatically alter investment in renewable energy utilization. The unstable regulations create uncertainty and force investors to re-think undertaking projects that can be completed even relatively quickly, but which will operate over an extended period. The most recent changes in the regulations guiding renewable energy utilization further illustrate the continuing instability surrounding the renewable energy sector. Although the regulations changed, this study provides a benchmark against which future investors may review their plans using alternative assumptions dictated by new conditions.

Discouraging investment in large commercial PV power plants by changing the returns on investment suggests a policy shift away from solar energy to other renewable energy sources because the EC-mandated share of renewable energy sources in the total energy generation remains unchanged. The change in the regulatory regime in 2017 appears to favuor microinstallations, allowing households to invest in PV equipment and connect to the grid. Such installations, which were outside the scope of this study, receive support under the currently EU-allocated funds and may be a focus of a future study examining their economic viability.

\section{Acknowledgements}

The authors express their appreciation to Laura Alfonso, Kevin Cook, Wojciech J. Florkowski, and Amanda Hollar for their assistance in the preparation of this study and critical comments. 


\section{Literatura}

Anderson, E., Dohan, C., Sikora, A., Bitar, S.J., McNeill, J.A. (2003). Solar Panel Peak Power Tracking System. Bachelor of Science Thesis. Worcester Polytechnic Institute.

Brick, K., Visser, M. (2009). Green certificate trading. University of Cape Town. G:Enesis. EPRU. Energy Research Centre.

Chandel, M., Agrawal, G.D., Mathur, S., Mathur, A. (2014). Techno-economic analysis of solar photovoltaic power plant for garment zone of Jaipur city. Case Study in Thermal Engineering, no. 2, pp. 1-7.

Chochowski,A. (2008a). Energetyka słoneczna. In: A. Chochowski, F. Krawiec (ed.) Zarzadzanie $w$ energetyce: koncepcje, zasoby, strategie, struktury, procesy i technologie energetyki odnawialnej (pp. 267-292). Difin.

Chochowski, A. (2008b). Energetyka wiatrowa. In: A. Chochowski, F. Krawiec (ed.), Zarzadzanie $w$ energetyce: koncepcje, zasoby, strategie, struktury, procesy i technologie energetyki odnawialnej. (pp. 255-266). Difin.

Chojnacki, I. (2018). Aukcje OZE. System ma szanse wreszcie zaczać działać. Retrieved from: https://energetyka.wnp.pl/aukcje-oze-system-ma-szanse-wreszcie-zaczac-dzialac,319882 _1_0_0.html (access date: 09.07.2018).

cire.pl(2017).Cenyreferencyjnewaukcjachna2018r.wedtugMinisterstwa Energii.Retrievedfrom: www.cire.pl/item, 155211,1,0,0,0,0,0,ceny-referencyjne-w-aukcjach-na-2018-r-wedlugministerstwa-energii.html (access date: 09.07.2018).

creconsulting.pl (2016). Retrieved from: www.cre-consulting.pl/sekcjainformacji/2_informacje-z-rynku/informacja/392_oxford-university--od-lat-80--panele-pv-tanieja-o-10-proc-rocznie.html, Oxford University: od lat 80 . panele PV tanieją o 10 proc. Rocznie (access date: 11.08.2016).

Czerska, J. (2002). Metody oceny efektywności projektów inwestycyjnych. Gdańsk: Politechnika Gdańska.

Drury, C. (1998). Rachunek kosztów. Warszawa: Wydawnictwo Naukowe PWN.

Dyrektywa Parlamentu Europejskiego i Rady 2009/28/WE z dnia 23 kwietnia 2009 r. w sprawie promowania stosowania energii ze źródeł odnawialnych zmieniająca i w następstwie uchylająca dyrektywy 2001/77/WE oraz 2003/30/WE, Dz.U. UE L 09.140.16. Retrieved from: http://www.ure.gov.pl/pl/prawo/prawo wspolnotowe/dyrektywy (access date: 10.08.2016).

energetyka.wnp.pl(2018).Aukcje OZE.Systemma szansęwreszcie zaczać działać. Retrieved from: https://energetyka.wnp.pl/aukcje-oze-system-ma-szanse-wreszcie-zaczac-dzialac,319882 _1_0_0.html (access date: 09.07.2018).

El-Shimy, M. (2009). Viability analysis of PV power plants in Egypt. Renewable Energy, no. 34, pp. 2187-2196.

EurObserv'ER(2014).The State of Renewable Energies in Europe. Edition 2014.14 ${ }^{\text {th }}$ EurObserv'ER Report. Retrieved from: http://www.eurobserv-er.org/14th-annual-overview-barometer (access date: 11.08.2016).

EurObserv'ER. (2015). Barometr fotowoltaiczny. Biuletyn Energii Odnawialnej Fotowoltaika. Retrieved from: http://www.eurobserv-er.org/category/barometers-in-polish (access date: 11.08.2016).

EurObserv'ER. (2016). Photovoltaic Barometer April. Retrieved from: www.eurobserv-er.org/ category/barometer-2016 (access date: 11.08.2016).

EurObserv'ER (2017). Photovoltaic Barometer April. Retrieved from: https://www.eurobserver.org/category/barometers-in-english/ (access date: 11.07.2018). 
Farmer, J.D., Lafond, F. (2016). How predictable is technological progress? Research Policy, no. 45 , pp. 647-665.

GUS (2017). Energia ze źródet odnawialnych w 2016 roku. Struktura pozyskania energii odnawialnej (wg źródeł) w wybranych krajach UE. Struktura produkcji energii elektrycznej zodnawialnych nośników energii w wybranych krajach UE. Retrieved from: https://stat.gov.pl/ obszary-tematyczne/srodowisko-energia/energia/energia-ze-zrodel-odnawialnych-w-2016roku,3,11.html. P. 27 and 30 (access date: 11.07.2018).

gramwzielone.pl (2015a). Retrieved from: http://gramwzielone.pl/energia-sloneczna/15805/ w-malopolsce-powstala-farma-fotowoltaiczna-na-trackerach (access date: 11.08.2016).

gramwzielone.pl (2015b). Ceny w aukcji dla PVw Niemczech od 0,01 EUR/kWh. Retrieved from: http://gramwzielone.pl/energia-sloneczna/17782/ceny-w-aukcji-dla-pv-w-niemczechod-001-eurkwh (access date: 11.08.2016).

gramwzielone.pl (2015c). Ceny referencyjne dla aukcji OZE na 2016 r. Retrieved from: http:// gramwzielone.pl/trendy/18093/ceny-referencyjne-dla-aukcji-oze-na-2016-r (access date: 11.08.2016).

gramwzielone.pl (2017). URE podat wyniki aukcji dla OZE z 29-30 czerwca. Retrieved from: http://gramwzielone.pl/trendy/27264/ure-podal-wyniki-aukcji-dla-oze-z-29-30-czerwca (access date: 04.07.2017).

Green Energy Poland SA. (2016). Zielone certyfikaty mechanizm działania, cena, zasady obro$t u$. Retrieved from: http://gepsa.pl/322-2/ (access date: 11.08.2016).

Harder, E., Mac Donald Gibson, J. (2011). The costs and benefits of large-scale solar photovoltaic power production in Abu Dhabi, United Arab Emirates. Renewable Energy, no. 36/2, pp. 789-796.

Instalacje budowlane (2017). Warunki nasłonecznienia Polski a kolektory. Retrieved from: http://www.instalacjebudowlane.pl/4011-77-12394-warunki-naslonecznienia-polski-a-kolektory.html (access date: 11.08.2016).

IRENA (2014). PV prices have declined $80 \%$ since 2008. Retrieved from: https://www.pv-magazine.com/2014/09/11/irena-pv-prices-have-declined-80-since-2008_100016383/ (access date: 11.08.2016).

Jeager-Waldau, A., Szabo, M., Scarlatk N., Monforti-Ferrario, F. (2011). Renewable electricity in Europe. Renewable and Sustainable Energy Reviews, no. 15, pp. 3703-3716.

Kahl, T. (1984). Sieci elektroenergetyczne. Warszawa: WNT.

Khalid, A., Junaidi, H. (2013). Study of economic viability of fhotovoltaic electric power for Quetta - Pakistan. Renewable Energy 50C, pp. 253-258.

Klepacka, A.M., Zalewska, J.I. (2016). Rozwój energetyki fotowoltaicznej w Polsce na tle UE (na przykładzie województwa mazowieckiego). Wieś Jutra, no. 1, pp. 40-44.

Klepacka, A.M., Buska, A. (2015). Ocena znajomości wykorzystania energii słonecznej oraz dofinansowania z budżetu rządowego rozwoju odnawialnych źródeł energii w opinii mieszkańców wybranych gmin powiatu włodawskiego. Wieś Jutra, no. 3, pp. 9-12.

Knyps, P. (2010). Zasoby słoneczne w Polsce. Retrieved from: http://pv.pl/zasoby-sloneczne-wpolsce (access date: 11.08.2016).

kolektorowo.pl (2016). Czym różnia się panele fotowoltaiczne od kolektorów słonecznych. Retrieved from: http://kolektorowo.pl/index.php/strefawiedzy/144-czym-roni-si-panelefotowoltaiczne-od-kolektorow-sonecznych (access date: 11.08.2016).

Laudyn,D. (1999). Rachunek ekonomiczny w elektroenergetyce. Warszawa: Oficyna Wydawnicza Politechniki Warszawskiej.

Ligus, M. (2009). Efektywność inwestycji w odnawialne źródta energii - analiza kosztów i korzyści. Warszawa: CeDeWu. 
Linden, N.H., van den Uyterlinde, M.A., Vrolijk, C., Nilsson, L.J., Khan, J., Ås Trand, K., Ericsson, K., Wiser, R. (2005). Review of International Experience with Renewable Energy Obligation Support Mechanisms, ECN. Retrieved from: http://www.ecn.nl/docs/library/report/2005/c05025.pdf (access date: 23.09.2016).

Lorenc, H. (2005). Atlas klimatu Polski. Warszawa: Instytut Meteorologii i Gospodarki Wodnej.

Magazyn Biomasa (2016). System aukcyjny od 1 lipca 2016 roku. Retrieved from: http://magazynbiomasa.pl/uruchomienie-systemu-aukcyjnego-prawdopodobnie-odroczone/ (access date: 23.09 .2016$)$.

Marcinek, K. (2002). Finansowa ocena przedsięwzięć inwestycyjnych przedsiębiorstw. $5^{\text {th }}$ edition. Katowice.

Mientus, K. (2011). Energia słońca-aspekty ekologiczne i ekonomiczne. Retrieved from: http:// www.cire.pl/pliki/2/MientusKrzysztof.pdf (access date: 23.09.2016).

Ministerstwo Energii (2016). KE potwierdziła zgodność polskiego systemu wsparcia OZE z unijnym prawem pomocy publicznej. Retrieved from: http://www.me.gov.pl/node/26262 (access date: 23.09 .2016$)$.

Narodowy Bank Polski (NBP). (2016). Retrieved from: http://www.nbp.pl/home.aspx?navi$\mathrm{d}=\operatorname{arch} a \& \mathrm{c}=/ \operatorname{ascx} / \mathrm{tab} \operatorname{arch} . \operatorname{ascx} \& \mathrm{n}=\mathrm{a} 125 \mathrm{z} 150701$ (access date: 23.09 .2016 ).

O’Brien, H. (2008). Team Sets Sight on Emerging Markets. Windpower, no. 10.

Obwieszczenie Marszałka Sejmu RP z dnia 16 maja 2006 r. w sprawie ogłoszenia jednolitego tekstu ustawy - Prawo energetyczne (Dz.U. 2006 r., no. 89, poz. 625). Retrieved from: http://prawo.sejm.gov.pl/isap.nsf/DocDetails.xsp?id=WDU20060890625 (access date: 25.03.2018).

odnawialnezrodlaenergii.pl (2018). Prezydent podpisał ustawe pozwalajaca na efektywniejsze wykorzystanie OZE. Retrieved from: http://odnawialnezrodlaenergii.pl/oze-aktualnosci/item/3916-prezydent-podpisal-ustawe-pozwalajaca-na-efektywniejsze-wykorzystanie-oze (access date: 09.07.2018).

Przewodnik dla przedsiębiorcy (2016). Centrum informacji o środowisku. Retrieved from: http://archiwum.ekoportal.gov.pl/dla_przedsiebiorcow_i_inwestorow/PoradnikDlaPrzedsiebiorcow/ WP_0.html (access date: 10.08.2016).

Räuber, A. (2004). Technologie wytwarzania i własności ogniw słonecznych. Freiburg; Warszawa: SOLTRAIN.

Renewable Energy Policy Network for the $21^{\text {st }}$ Centry (REN21). (2016). Renewables Global Status Report. Retrieved from: http://www.iaea.org/inis/collection/NCLCollectionStore/_ Public/46/105/46105561.pdf (access date: 11.08.2016).

Rogowski, W. (2008). Rachunek efektywności inwestycji. Kraków: WoltersKluwer.

Rynek Praw Majątkowych (2016). Towarowa Giełda Energii S.A. Retrieved from: https://www. tge.pl/fm/upload/Wszystko-o-RPM/FolderRPM.pdf (access date: 10.08.2016).

Sawicki, K. (1998). Podstawy rachunkowości. Warszawa: Wydawnictwo Naukowe PWN.

Sefa, I., Demirtas, M., Colak, I. (2009). Application of one-axis tracking system. Energy Conversion and Management, no. 50(11), pp. 2709-2718.

Schnell, C. (2018). System aukcyjny po notyfikacji i cel OZE. Retrieved from: https://wysokienapiecie.pl/7435-system-aukcyjny-po-notyfikacji-cel-oze/\#dalej) (access date: 09.07.2018).

Tudorache, T., Kreindler, L. (2010). Design of a Solar Tracker System for PV Power. Acta Polytechnica Hungarica, vol. 7, no. 1, pp. 23-39.

URE podat wyniki aukcji dla OZE z 29-30 czerwca (2017). Retrieved from: http://gramwzielone. $\mathrm{pl} /$ trendy/27264/ure-podal-wyniki-aukcji-dla-oze-z-29-30-czerwca (access date: 09.07.2018). 
Urząd Regulacji Energetyki (2016b). Rusza testowa wersja Internetowej Platformy Aukcyjnej (IPA) sprzedaży energii elektrycznej z odnawialnych źródet energii. Retrieved from: http://www. ure.gov.pl/pl/urzad/informacje-ogolne/aktualnosci/6551,Rusza-testowa-wersja-InternetowejPlatformy-Aukcyjnej-IPA-sprzedazy-energii-elek.html (access date: 11.08.2016).

Ustawa z dnia 20 lutego 2015 r. o odnawialnych źródłach energii (Dz.U. 2015 r., poz. 478). Retrieved from: http://prawo.sejm.gov.pl/isap.nsf/DocDetails.xsp?id=WDU20150000478; http://orka.sejm.gov.pl/proc7.nsf/ustawy/2604_u.htm (access date: 25.03.2018).

Ustawa z dnia 22 czerwca 2016 r. o zmianie ustawy o odnawialnych źródłach energii oraz niektórych innych ustaw (Dz.U. 2016 r., poz. 925). Retrieved from: http://prawo.sejm.gov.pl/ isap.nsf/DocDetails.xsp?id=WDU20160000925 (access date: 25.03.2018).

Wiśniewski, G. (2017). Pierwsza aukcja na energię z OZE i co z niej wynika. „Odnawialny” Blog. Retrieved from: http://odnawialnezrodlaenergii.pl/oze-aktualnosci/item/3916-prezydent-podpisal-ustawe-pozwalajaca-na-efektywniejsze-wykorzystanie-oze (access date: 09.07.2018). 


\title{
ZWROT Z INWESTYCJI FARMY FOTOWOLTAICZNEJ W RAMACH ZMIENIAJACYCH SIĘ PRZEPISÓW
}

\begin{abstract}
Abstrakt
Produkcja energii odnawialnej rośnie w Polsce zgodnie z mandatem UE. Wykorzystanie energii słonecznej jest $w$ szczególności uzależnione od przepisów $i$ związanego z nimi mechanizmu subsydiowania. Celem prezentowanego badania jest analiza pięciu scenariuszy z wykorzystaniem danych finansowych i operacyjnych udostepnionych przez istniejaca elektrownie fotowoltaiczna w Jadownikach. Dwa scenariusze dotycza założen działajacych $w$ ramach mechanizmu wsparcia stosowanego przed 1 lipca 2016 r., natomiast trzy scenariusze dotycza założén działajacych $w$ ramach systemu aukcyjnego, który stat się mechanizmem wsparcia dla producentów energii odnawialnej od 1 lipca 2016 r. Scenariusze I i II generuja dodatnia wartość NPV oraz IRR w założonych warunkach, w tym z wykorzystaniem zielonych certyfikatów. W przypadku elektrowni PV działajacych od 1 lipca 2016 r. scenariusze III i IV pokazuja, że zwrot zależy od ceny aukcji, a wielkość NPV $i$ IRR zniechęca do inwestycji. Scenariusz. V zakłada brak wsparcia w postaci zielonych certyfikatów lub systemów aukcyjnych i generuje straty. Ciagłe zmiany $w$ regulacji wytwarzania energii z odnawialnych źródeł energii, $w$ tym energii słonecznej, stwarzają niepewność, która może zniechęcić do inwestowania w duże komercyjne elektrownie PVw Polsce.
\end{abstract}

Słowa kluczowe: elektrownia PV, zwrot z inwestycji, reżim regulacyjny.

Accepted for print: 5.09 .2018 .

O ile nie jest to stwierdzone inaczej, wszystkie materiały na stronie są dostępne na licencji

Creative Commons Uznanie Autorstwa 4.0 Międzynarodowe.

Pewne prawa zastrzeżone na rzecz Instytutu Ekonomiki Rolnictwa i Gospodarki Żywnościowej - PIB.

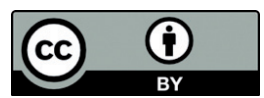

